\title{
Where Economic Development Meets the Rule of Law? Promoting Sustainable Development Goals Through the European Neighborhood Policy
}

\author{
Maryna Rabinovych \\ PhD Candidate, Faculty of Law, University of Hamburg \\ Marinarabi93@gmail.com
}

\begin{abstract}
The 2030 Agenda and pertinent EU law and policy are marked by an emphasis on the interlinkages between the Sustainable Development Goals. With this in mind, this article explores whether the Agenda and the respective EU law and policy offer a conceptually clear and instrumental vision of the interlinkages between economic development (Goal 8) and the rule of law (Goal 16). It is argued that both the Agenda and relevant EU policies view the rule of law both as an independent value and as an instrument of economic development, without distinguishing the components that rule of law is comprised of. The article discusses the Eastern dimension of the European Neighborhood Policy as a case study to contextualize the analysis. Based on its findings regarding the interlinkages between the rule of law and economic development in the 2030 Agenda and relevant EU policy, the article also sets out certain policy recommendations for creating a sustainable development-oriented design of the Eastern dimension of the European Neighbourhood Policy.
\end{abstract}

\section{Keywords}

2030 Agenda - rule of law - economic development - interlinkages between the goals - policy coherence 


\section{Introduction ${ }^{1}$}

The United Nations (UN) 2030 Agenda for Sustainable Development ('Agenda' or '2030 Agenda'), adopted by the UN General Assembly (UNGA) on 25 September 2015, represents a comprehensive 'plan of action for people, planet and prosperity.' ${ }^{2}$ Building on the Millennium Development Goals (MDGs) ${ }^{3}$ and the follow-up from the Rio+ 20 Conference on Sustainable Development, ${ }^{4}$ the Agenda sets 17 Sustainable Development Goals (SDGs) and 169 targets. ${ }^{5}$ Based on the concept of 'sustainable development', the 2030 Agenda is marked by an emphasis on the interplay between the economic, social and environmental aspects of development. ${ }^{6}$ Adopting the 'integrated approach' towards the implementation of the Goals, the Agenda underlines the importance of the interlinkages between the sDGs and 'many cross-cutting elements across the new Goals.' ${ }^{7}$ distinguishes finance, trade, capacity development and technology as such 'cross-cutting elements', and calls for policy coherence for sustainable development. ${ }^{8}$ Moreover, Goal 17 focuses on 'strengthening the means of implementation and revitalizing the global partnership for sustainable development'.

The European Union's (EU) response to the adoption of the 2030 Agenda is featured in the Commission's 2016 Communication Next Steps for a Sustainable European Future: European Action for Sustainability (Next Steps for a Sustainable European Future)..$^{9}$ Pursuant to the Communication, 'the EU is fully committed to be a frontrunner in implementing the 2030 Agenda and the

1 The Special Issue 'International Law for the Sustainable Development Goals' is a research outcome of the 2017-2018 Workshop Series 'International Law for the Sustainable Development Goals' organised by the Department of Transboundary Legal Studies, Faculty of Law, University of Groningen. Mando Rachovitsa and Marlies Hesselman led the organisation of these workshops. The series included 8 workshops which explored the role and relevance of international law to the implementation of the Sustainable Development Goals. The Special Issue includes some of the papers presented at the workshops and papers submitted to an open Call for Papers. More information is available at https://www.rug.nl/rechten/ congressen/il4sdgs/.

2 UNGA, Transforming Our World: The 2030 Agenda for Sustainable Development, A/RES/70/1, 25 September 2015, p. 3.

3 UNGA, United Nations Millennium Declaration, A/RES/55/2, 18 September 2000.

4 UNGA, The Future We Want, A/RES/66/288, 27 July 2012.

5 Transforming Our World: The 2030 Agenda for Sustainable Development.

6 Ibid., p. 1.

7 Ibid., pp. $5^{-6 .}$

8 Ibid., p. 26.

9 European Commission, Next Steps for a Sustainable European Future: European Action for Sustainability, СОм (2016)739final, 22 November 2016. 
SDGs. ${ }^{10}$ The EU's commitment to the 2030 Agenda is reaffirmed by the 2017 New European Consensus on Development that structurally mirrors the 2030 Agenda. ${ }^{11}$ Placing the implementation of the Goals into the heart of the discussion, the 2017 New European Consensus on Development advocates for 'particular attention to such interlinkages [between the Goals] and to integrated actions that can create co-benefits and meet multiple objectives in a coherent way'.12

Both the Agenda and the EU's implementing documents underline the role of the rule of law and of 'effective, accountable and inclusive institutions' in achieving sustainable development. ${ }^{13}$ An ambition to link legal and economic development goes in line with international donors' ever increasing attention to recipients' legal systems. ${ }^{14}$ Furthermore, the link between legal and economic development is close to the core of the $\mathrm{EU}$ project of promoting peace through economic development and legal integration. ${ }^{15}$ In its external dimension of the EU, the closer nexus between economic and legal development follows the coherence-oriented reform, which was introduced by the Lisbon Treaty, whereby the EU granted democracy, human rights and the rule of law the status of guiding principles and objectives of its external action. ${ }^{16}$

Despite the global and EU's ambition to stress the interlinkage between the rule of law and economic development, it remains questionable whether the Agenda and the respective EU documents so far offer a conceptually clear and instrumental vision of this interlinkage, capable of being translated into external policies of the EU. This article aims to explore how the relationship between the rule of law (Goal 16) and economic development (Goal 8)

$10 \quad$ Ibid., p. 3.

11 Joint Statement by the Council and the Representatives of the Governments of the Member States Meeting within the Council, the European Parliament and the European Commission, TheNewEuropean ConsensusonDevelopment- 'OurWorld, OurDignity, OurFuture', 26 June 2017, https://ec.europa.eu/europeaid/sites/devco/files/european-consensus -on-development-final-20170626_en.pdf, accessed 1 February 2019.

12 Ibid., p. 8.

13 Transforming Our World: The 2030 Agenda for Sustainable Development, p. 2; New European Consensus on Development, p. 32.

14 See, for instance, Tor Krever, 'The Legal Turn in Late Development Theory: The "Rule of Law" and the World Bank's Development Model', Harvard International Law Journal, 52/1: 287-319 (2011), pp. 287-289.

15 Vicki Birchfield, John Krige and Alasdair Young, 'European Integration as a Peace Project', British Journal of Politics and International Relations, 19/1: 3-12 (2017), p. 7.

16 Consolidated version of the Treaty on European Union, Official Journal, C 326, 26 October 2012, https://eur-lex.europa.eu/legal-content/EN/TXT/?uri=celex\%3A12012M\%2FTXT, accessed 1 February 2019, (TEU (L)), Article 21(1) and Article 21(2)(a)(b) respectively. 
is framed in the 2030 Agenda and in the EU's development policy documents. The analysis subsequently uses these insights to suggest a sustainable development-oriented design of the Eastern dimension of the European Neighbourhood Policy (ENP). It is argued that the 2030 Agenda and respective EU development policies view the rule of law both as an independent value and as an instrument of promoting economic development, without distinguishing the components that the rule of law is comprised of. In theoretical terms, the interlinkages between the rule of law and economic development are discussed from the viewpoint of leading post-war development economics theories, such as modernization, dependency and world systems theory, new institutional economics, governance and new constitutionalism. The Eastern dimension of the ENP as a focus point for discussion is chosen on the basis of three reasons. First, the Communication Next Steps for a Sustainable European Future mentions the ENP as a pivotal instrument of the SDGs' external implementation. ${ }^{17}$ Second, the Eastern dimension of the ENP has long been a focus of both the EU's support to economic development and external promotion of EU's fundamental values (Article $2 \mathrm{TEU}$ ). ${ }^{18}$ Third, since the ENP has not yet been revisited in line with the 2030 Agenda, it is of particular interest to explore the added value that a sustainable development-oriented design could bring to the ENP. The article focuses mainly on the economic development dimension of the sustainable development concept. However, since the very idea of sustainable development presupposes multiple interlinkages between its economic, environmental and social aspects, the discussion tangentially refers to its environmental and social dimensions, while defining economic development.

The paper is structured as follows. Section 2 explores the conceptualizations of the concepts economic development and rule of law from the viewpoints of Goal 8 and Goal 16 as well as EU development policy and establishes working definitions for these concepts. Relying on these definitions, Section 3 focuses on existing development economics theories' perspectives regarding the interlinkages between the rule of law and economic development, and applies their critical insights in an exploration of the interlinkages between the rule of law and economic development in the 2030 Agenda and the EU policy. Section 4 discusses and sets out a series of policy recommendations regarding the sustainable development-oriented design of the ENP.

17 Next Steps for a Sustainable European Future, p. 13.

18 TEU (L), Article 2; Tobias Schumacher and Dimitris Bouris, 'The 2011 Revised European Neighbourhood Policy: Continuity and Change in EU Foreign Policy' in Dimitris Bouris and Tobias Schumacher (eds.), The Revised European Neighbourhood Policy: Continuity and Change in EU Foreign Policy (London: Palgrave McMillan, 2017), pp. 2-3. 
This section analyses different perspectives that exist in relation to the concepts of economic development and the rule of law within the 2030 Agenda and the EU. However, before discussing these concepts, it is important to make the following observations underlying the discussion: the problematique of developing a comprehensive vision of the interlinkages between the rule of law and economic development is plagued by several features that these concepts share. First, the substance of these concepts is never fixed, since it keeps transforming due to the changing policy and legal contexts. Second, as exemplified by the idea of sustainable development, both concepts are complex and related to multiple phenomena. Thus, the concepts' complexity and vulnerability to changes bring them close to Gallie's famous category of 'essentially contested' concepts, ${ }^{19}$ whose application would require contextualization efforts. Thus, this section contextualizes economic development and rule of law with regard to the 2030 Agenda and relevant EU policy documents.

\subsection{Economic Development as Part of Sustainable Development: The Shifting Balance Between Economic, Social and Environmental Dimensions?}

2.1.1 The Concept of Economic Development in the 2030 Agenda

In scholarship, there are numerous approaches to economic development, ranging from the narrow ones, equating it to growth, to more expansive perspectives, involving multiple factors, such as life expectancy and literacy. ${ }^{20}$ As argued by the U.S. economist, Robert Lukas, all such factors are still inevitably correlated to the per capita Gross National Income (GNI). ${ }^{21}$ Nonetheless, the concept of sustainable development, as the core of the 2030 Agenda, goes beyond the GNI-focus and represents a three-dimensional model, involving economic, environmental and social aspects. ${ }^{22}$

Having collated the concepts of inclusive and sustainable development, as contained in the 2030 Agenda, ${ }^{23}$ Gupta and Vegelin, underline that, despite the

\footnotetext{
19 Walter Boyce Gallie, 'Essentially Contested Concepts', Proceedings of the Aristotelean Society, 56/1: 167-198 (1956), pp. 170-172.

20 Jaime Ros, The Economics of Growth (Michigan: University of Michigan Press, 2001), pp. $16-20$.

21 Robert Lukas, 'On the Mechanics of Economic Development', Journal of Monetary Economics, 22/1: 3-42 (1988), p. 3.

22 Transforming Our World: The 2030 Agenda for Sustainable Development.

23 Elena Dugarova, 'Social Inclusion, Poverty Eradication and the 2030 Agenda for Sustainable Development', UNRISD Papers, 14: 1-3 (2015).
} 
strengthening of a notion of social inclusion, 'the SDG document continues to emphasize growth in its interpretation of sustainable development'. ${ }^{24}$ The authors substantiate the above statement by the fact that eco-centric targets across numerous Goals (e.g. Goals 1, 2, 6, 7, 8) are imprecise, non-measurable and do not elaborate either on the way rights, responsibilities and risks are shared among various groups or on how international cooperation shall be reformed to implement the above targets. ${ }^{25}$ Furthermore, the analysis of the targets and indicators related to the economic growth dimension of Goal 8 reveals that Goal 8 is preoccupied with per capita GNI. ${ }^{26}$ Thereby the social inclusion aspect of sustainable development is predominantly featured through employment-related targets (e.g., targets 8.5, 8.7, 8.8). ${ }^{27}$ Furthermore, following an analysis of the employment-related targets of the 2030 Agenda from the standpoint of international human rights law, Frey and McNaughton find that 'the new 2030 development agenda sadly aligns with market-based economic growth strategies rather than the realization of the human rights to full employment and decent work for all: ${ }^{28}$ The key reasons for such conclusions include the solitary and imprecise references to labor rights and ILO textual sources in target 8.8 and indicator 8.8.2 and the gap between the targets under the SDGs and the ILO Decent Work Agenda. ${ }^{29}$ Moreover, the sole environmental target 8.4 under Goal 8 is formulated in rather soft terms as an 'endeavor to decouple economic growth from environmental degradation'. ${ }^{30}$ Drawing lessons from the global and EU experience of environmental policy integration, Adelle and Nilsson also point to the 'softness' and lacking instrumentality of this formulation, especially in comparison with the precise formulations of

24 Joyeeta Gupta and Courtney Vegelin, 'Sustainable Development Goals and Inclusive Development', International Environmental Agreements: Politics, Law and Economics, 16/3: 433-448 (2016).

$25 \quad$ Ibid., pp. 437-438.

26 Inter-Agency and Expert Group on Sustainable Development Goals Indicators, Final List of Sustainable Development Goals Indicators, E/CN.3/2016/2/Rev.1, 11 March 2016, pp. 10-11, https://sustainabledevelopment.un.org/content/documents/11803Official-List-of-Proposed-SDG-Indicators.pdf, accessed 1 February 2019.

27 Ibid.

28 Diane F. Frey and Gillian McNaughton, 'A Human Rights Lens on Full Employment and Decent Work in the 2030 Sustainable Development Agenda', Journal of Workplace Rights, April/June 2016: 1-13, p. 9 .

29 Ibid., pp. 2-4.

30 Inter-Agency and Expert Group on Sustainable Development Goals Indicators, Final List, pp. 10-11. 
growth-related targets and indicators (e.g. target 8.1 and 8.2., indicators 8.1.1 and 8.2.1). ${ }^{31}$

Thus, even though the 2030 Agenda as a whole and the wording of Goal 8 in particular, are pierced by the three-dimensional approach to development, economic growth represents a key priority for this Goal especially. Less precise and often non-measurable formulations of targets and indicators related to environmental and social inclusiveness dimensions of economic development under Goal 8 allow for greater flexibility with regard to the implementation of Goal 8 and may be simultaneously misused by States by making only "cosmetic" reforms.

2.1.2

Environmental Focus in the EU's Concept of 'Economic

Development' Prior to the sDGs' Adoption

Pursuant to the 1957 formulation in the (then) E EC Treaty, the establishment of the common market and resulting progressive approximation of the Member States' economies were aimed at the 'harmonious development of economic activities' throughout the (then) Community. ${ }^{32}$ The 1992 Treaty of Maastricht (TEU $(\mathrm{M})$ ) was the first one to formalize the notion of sustainability by referring to 'sustainable non-inflationary growth respecting the environment'. ${ }^{33}$ Despite having been criticized for avoiding the legal commitment to sustainable development in the TEU (M), ${ }^{34}$ the EU only undertook respective commitments under Articles 3 and 21 of the Treaty of Lisbon (TEU (L)) in 2009. ${ }^{35}$ Pursuant to Article 3(3) TEU (L), the internal market 'shall work for the sustainable development of Europe based on balanced economic growth and price stability' ${ }^{36}$ According to Article 3(5) TEU, 'in its relations with the wider world [...] the Union shall uphold and promote its values and interests and contribute to the

31 Camilla Adelle and Mans Nilsson, 'Environmental Policy Integration' in Philipp Rattberg and Fariborz Zelli (eds.), Encyclopedia of Global Environmental Policy and Governance (Cheltenham: Edward Elgar Publishing, 2015), pp. 456-457.

32 Treaty Establishing the European Economic Community, 25 March 1957, https://eurlex.europa.eu/legal-content/FR/TXT/PDF/?uri=CELEX:11957E/TXT\&from=EN, accessed 1 February 2019.

33 Treaty on European Union, Official Journal, C191, 29 July 1992, https://eur-lex.europa .eu/legal-content/EN/TXT/?uri=celex:11992M/TXT, accessed i February 2019, (TEU (M)), Article 2.

34 Maria Kenig-Witkowska, 'The Concept of Sustainable Development in the European Union Policy and Law', Journal of Comparative Urban Law and Policy, 1/1: 64-80 (2017), p. 65 .

35 TEU (L), Articles 3 and 21.

$36 \quad$ Ibid., Article 3. 
protection of its citizens. It shall contribute to peace, security, the sustainable development of the Earth' ${ }^{37}$ The EU's obligation to promote sustainable development externally is complemented by Article $21(2)(d) \mathrm{TEU}$ that stipulates 'fostering the sustainable economic, social and environmental development of developing countries, with the primary aim of eradicating poverty' as the objective of the EU's common policies and actions, and cooperation with third states and international organizations. ${ }^{38}$

However, before the adoption of the SDGs' and the Treaty of Lisbon, the concept of sustainable development was addressed in a number of policy documents, such as the 2001 European Union Strategy for Sustainable Development (2001 EU Strategy for Sustainable Development). ${ }^{39}$ Pursuant to the 2001 EU Strategy for Sustainable Development, sustainable development combines economic growth, social cohesion and environmental protection policies, meeting the needs of the present generations without 'compromising the ability of future generations to meet their own needs'. ${ }^{40}$ The 2001 EU Strategy for Sustainable Development bears a strong environmental focus, emphasizing the reforms of climate change, biodiversity and resource management policies ${ }^{41}$ The 2006 Review of the 2001 EU Strategy for Sustainable Development distinguishes four major objectives of sustainable development: environmental protection, social cohesion, economic prosperity and meeting the EU's international responsibilities. ${ }^{42}$ Further strengthening the environmental focus, the 2006 Review barely points to intra-EU economic growth and emphasizes the external dimension of growth promotion. ${ }^{43}$

A conceptual shift in the understanding of growth was introduced in 2010 by the Europe 2020 Strategy. Pursuant to the Europe 2020 Strategy, growth entails the dimensions of smartness (knowledgeable economy), sustainability (resource efficient, green and competitive economy) and inclusiveness (involving economic, social and territorial cohesion).$^{44}$ Despite the growth-focused wording, the targets of the Europe 2020 Strategy include a strong environmental

37 TEU (L), Article 3(5).

38 TEU (L), Article 21(2)(d).

39 European Commission, Communication, A Sustainable Europe for a Better World: A European Union Strategy for Sustainable Development, COM/2001/0264/final, 15 May 2001.

$40 \quad$ Ibid., p. 1.

41 Ibid.

42 Council of the European Union, Review of the EU Sustainable Development Strategy (EU SDS), 10917/o6, 26 June 2006.

43 Ibid., pp. 2-3.

44 European Commission, Communication, Europe 2020 - A Strategy for Smart, Sustainable and Inclusive Growth, Сом(2010) 2020, 3 March 2010. 
dimension. ${ }^{45}$ With respect to the EU's "export" of sustainable development, the 2011 Agenda for Change concentrates on green economy and sustainable management of national resources. ${ }^{46}$

Ultimately, before undertaking the commitment to SDGs, the EU developed its own conceptualization of sustainable economic development that includes the dimensions of "smartness", sustainability and inclusiveness. ${ }^{47}$ Marked by a strong emphasis on environmental protection, the previously discussed EU policy documents aim at mitigating the contradiction between growth and environmental protection and viewing better governance and innovation as the pathways to sustainable growth. ${ }^{48}$

2.1.3

The EU's Conceptualization of Economic Development Following the Adoption of the SDGs

The analysis of the EU's post-SDGs policies showcases its effort to reach smart, sustainable and inclusive growth both internally and externally. ${ }^{49}$ In this spirit, the Commission's Next Steps for a Sustainable European Future and the 2017 New European Consensus on Development resemble a stronger nexus between growth, investment and new financial instruments, and environmental action. ${ }^{50}$ Internally, the Europe 2020 Strategy's understanding of sustainable development remains topical, complemented by an emphasis on private investment. ${ }^{51}$ Despite the fact that Goal 8 is linked to growth and employment targets, the EU seeks to promote the achievement of Goal 8 via environmentrelated instruments both internally and externally. ${ }^{52}$ Notably, internally, the EU offers a range of environmental protection instruments, such as the EU's Environment Action Programme 2020 or the Blue Growth Strategy. ${ }^{53}$ Externally, however, the EU suggests a stronger linkage between poverty eradication, economic growth and inclusiveness, rather than economic growth and

45 Ibid., pp. 12-15.

46 European Commission, Increasing the Impact of EU Development Policy: An Agenda for Change,

47 Europe 2020 - A Strategy for Smart, Sustainable and Inclusive Growth.

48 Ibid., pp. 3, 7; European Commission, Rio+20: Toward the Green Economy and Better Governance, $\operatorname{com}(2011)$ 0363final, 20 June 2011, pp. 8-10.

49 Next Steps for a Sustainable European Future; European Commission, Staff Working Document, Key European Action Supporting the 2030 Agenda and the Sustainable Development Goals, $\operatorname{SwD}(2016)$ 39ofinal, 22 November 2016.

50 See, for instance, Key European Action Supporting the 2030 Agenda, pp. 28-30.

$5^{1} \quad$ Ibid., p. 28.

$5^{2} \quad$ Ibid., pp. $28-32$.

53 Ibid., p. 38. 
environment protection. ${ }^{54}$ As opposed to the EU's internal policy on Goal 8, the external environmental aspect thereof tackles selective issues (e.g., support to resource-efficiency or lowering $\mathrm{CO}_{2}$ emissions), rather than develops comprehensive action frameworks. ${ }^{55}$ This argument can be substantiated by the analysis of the EU's development policies prior and after the SDGs' adoption by Adelle et al, who warn that the EU's growth-centeredness might diminish the importance of environmental objectives in terms of the EU's development cooperation. ${ }^{56}$

It is evident that the EU's commitment to implement the SDGs did not change much in its conceptual approach to economic development, but led to the shift of focus. Internally, this shift includes an emphasis on financial instruments for growth. Externally, in line with the growth-oriented Goal 8, the EU introduced a link between the promotion of economic development and poverty reduction, devaluating the environmental aspect. The remainder of this article will distinguish between the EU's internal and external understandings of economic development, viewing the latter as predominantly growth-oriented.

\section{Understanding?}

2.2.1 The Rule of Law in the 2030 Agenda

The 2030 Agenda refers to law in several contexts. First, the full respect for international law' is a guiding principle of the Agenda. ${ }^{57}$ Second, the Agenda mentions the rule of law as a component of 'enabling environment for sustainable development at all levels by all actors,, 58 Third, the promotion of the rule of law at the international and national levels is mentioned as a target under Goal $16 .{ }^{59}$ Despite the fact that the Agenda does not define the rule of law itself, an analysis of the wording of the Goal 16 allows making several remarks.

First, Goal 16 distinguishes between the international and national rule of law. ${ }^{60}$ This formulation is designed to reinforce States' commitments to

$54 \quad$ Ibid., pp. 28-32.

55 New European Consensus on Development, pp. 20-22.

56 Camilla Adelle et al., 'Environmental Instruments in Development Cooperation: Promoting Better Development and Environmental Outcomes?' in Camilla Adelle, Katja Biedenkopf and Diarmuid Tourney (eds.), European Union's External Environmental Policy Rules, Regulations and Governance beyond Borders (London: Palgrave McMillan, 2018), pp. 81-101.

57 Transforming Our World: The 2030 Agenda for Sustainable Development, p. 3.

58 Ibid., pp. 4, 9 .

59 Ibid., pp. 25-26.

6 Ibid., pp. $25^{-26 .}$ 
international law and raise attention to the interfaces between international and domestic law. ${ }^{61}$ According to Kanetake, such interfaces include the domestic interpretation, application and contestation of international law norms: 'the institutional divisions of power between national and international institutions and the relationship between the national and international adjudicative bodies'. ${ }^{2}$ Second, Goal 16 approaches the rule of law in a narrow sense, disentangling it from the protection of human rights, non-discrimination, countering corruption and accountability, transparency and effectiveness of institutions. ${ }^{63}$ Finally, the formulation of Goal 16 utilizes multiple concepts, such as 'access to justice' (target 16.3), 'effective, accountable and transparent institutions' (target 16.6), 'protection of fundamental freedoms' (target 16.10) and 'promotion and enforcement of non-discriminatory laws' (target 16B). On the one hand, the use of a number of concepts instead of a broad substantive understanding of the rule of law may help to make targets and indicators more specific. On the other hand, the textual analysis of Goal 16 does not allow for clarifying the content of the rule of law (target 16.3) or specifying the relationship between the rule of law and the abovementioned notions. This, in turn, makes it hard to assess countries' implementation of targets under Goal 16, especially target 16.3 .

2.2 .2

The Rule of Law in the EU Legal System Prior to the Adoption of the SDGs

Characterized by both aspirational and substantive characteristics, the concept of rule of law was first featured in the famous Hallstein's dictum ${ }^{64}$ and the landmark Les Verts case. ${ }^{65}$ Notwithstanding the conceptual gap between Hallstein's concept of Rechtsgemeinschaft and the cJEu's notion of the 'Community based on the rule of law', it shall be underlined that the Les Verts judgment already viewed the rule of law as a constitutional principle of the

\section{$61 \quad$ Ibid.}

62 Machiko Kanetake, 'The Interfaces between National and International Rule of Law: A Framework Paper' in Machiko Kanetake and Andre Nollkaemper (eds.), The Rule of Law at the National and International Levels (London: Hart Publishing, 2016), pp. 1-24.

63 The above concepts are contained in the following targets: Target 16.3 'Promote the rule of law at the national and international levels and ensure equal justice for all'; target 16.5 'Substantially reduce corruption and bribery in all forms'; target 16.6 'Develop effective, accountable and transparent institutions at all levels' and target 16.B 'Promote and enforce non-discriminatory laws and policies for sustainable development'.

64 Walter Hallstein, Europäische Reden (Stuttgart: hrsg. Thomas Opperman, 1979), p. 109.

65 Case 294/83, Parti écologiste 'Les Verts' v. European Parliament, 23 April 1986, ECLI: EU:C:1986:166. 
(then) European Community. ${ }^{66}$ Substantially, this principle was, however, limited to the institutions' and Member States' obligation to adhere to the Treaties. ${ }^{67}$

The politicization of the relationship between the (formerly) EC Member States in the post-Cold War era determined the fact that the rule of law was included into the TEU (M), although that treaty did not define either the legal status or the substance of this concept. ${ }^{68}$ The Treaty of Amsterdam (TEU(A)) addressed the rule of law as the EU's 'founding principle', a criterion for EU membership and an objective of the Common Foreign and Security Policy (CFSP). ${ }^{69}$ Following an 'ambiguous vocabulary change' from the concept of 'founding principle' to 'founding value, ${ }^{70}$ the Treaty of Lisbon (TEU (L)) mentioned the rule of law among the EU's founding values ${ }^{71}$ and an objective of institutions' action. ${ }^{72}$ In tune with the trend of the constitutionalization of foreign policy objectives, external value-promotion became the overarching objective of the EU external action..$^{73}$ Neither of these developments, however, shed light on the substance of the rule of law. Difficulties pertaining to the conceptualization of the rule of law include the different constitutional traditions of Member States, ${ }^{74}$ the fuzzy boundary between democracy and the rule of law, ${ }^{75}$ and the ambiguous nexus between the EU's external value-promotion and the pursuit of its geopolitical interests. ${ }^{76}$

66 Laurent Pech, 'The Rule of Law as a Constitutional Principle of the European Union', Jean Monnet Working Paper 04/o9, (2009), p. 13, https://papers.ssrn.com/sol3/papers.cfm? abstract_id=1463242, accessed 1 February 2019.

$67 \quad$ Ibid.

68 TEU (M), Article 2.

69 Treaty of Amsterdam amending the Treaty on European Union, the Treaties establishing the European Communities and certain related acts. Official Journal, $\mathrm{C}_{340}, 10$ November 1997, https://eur-lex.europa.eu/legal-content/EN/TXT/?uri=CELEX\%3A11997D\%2FTXT, accessed 1 February 2019 (TEU (A)), Article 8, Article J.1.

70 Pech, 'The Rule of Law as a Constitutional Principle of the European Union', p. 20.

71 TEU (L), Article 2.

72 TEU (L), Articles 3, 13.

73 Joris Larik, Foreign Policy Objectives in European Union Constitutional Law (Oxford: Oxford University Press, 2016), p. 127.

74 Pech, 'The Rule of Law as a Constitutional Principle of the European Union', pp. 22-47.

75 See, for instance: Guillermo O'Donnell, 'Why the Rule of Law Matters', Journal of Democracy, 15/4: 32-46 (2004).

76 Annette Jünemann, 'Security-Building in the Mediterranean After September 11', Mediterranean Politics, 8/2-3: 1-20 (2007); Tanja A. Börzel, 'The Noble West and the Dirty Rest? Western Democracy Promoters and Illiberal Regional Powers', Democratization, 22/3: $519-535$ (2015). 
Thus, the substance of the rule of law as an EU founding value has become the subject of debate only following the outbreak of the rule of law crises in Poland and Hungary in 2014-2015. ${ }^{77}$ Seeking to address these developments without immediately triggering the sanctions mechanism under Article 7 TEU, the Commission introduced the 2014 Rule of Law Framework as an instrument for facilitating dialogue between the Commission and concerned countries. ${ }^{78}$ Based on the case law of the CJEU and the European Court of Human Rights as well as the Council of Europe 2016 Rule of Law Checklist, ${ }^{79}$ the 2014 Rule of Law Framework offers a broad "consensual" concept of the rule of law, embracing the principles of legality, legal certainty, prohibition of arbitrariness of executive powers, authorities' independence and impartiality, and equality before the law and non-discrimination. ${ }^{80}$ Although the 2014 Rule of Law Framework was developed with respect to the internal dimension of the rule of law, it also provides a roadmap for the present discussion, whilst acknowledging the open-endedness of the debate on the substance of the external dimension of the rule of law in the EU. 81

\subsubsection{The Rule of Law and the SDGs: Towards Integrated Action and}

a Consensual Approach

Similarly to the case of sustainable development, the EU's commitment to the SDGs did not alter the substance of the EU's rule of law concept, but supplemented it with new emphases. Internally, the Commission's Next Steps for a Sustainable European Future links the rule of law to effective justice systems. ${ }^{82}$ In external terms, this document takes a general approach, mentioning the rule of law among the objectives of the EU's Enlargement and Neighbourhood policies. ${ }^{83}$ In internal terms, the implementation of Goal 16 is exercised through numerous EU legal instruments, such as the European area of freedom,

77 Heather Grabbe and Stefan Lehne, 'Defending EU Values in Poland and Hungary', 4 September 2017, http://carnegieeurope.eu/2017/og/04/defending-eu-values-in-poland-andhungary-pub-72988, accessed accessed 1 February 2019.

78 European Commission, A New EU Framework to Strengthen the Rule of Law, сом(2014) 0158 final, 11 March 2014.

79 European Commission for Democracy through Law, Rule of Law Checklist, Study No 711/2013, 18 March 2016 (adopted by the Venice Commission and endorsed by the Ministers' Deputies), http://www.venice.coe.int/webforms/documents/default.aspx?pdffile=CDL$\mathrm{AD}$ (2016)oo7-e, accessed 1 February 2019.

8o A New EU Framework to Strengthen the Rule of Law.

81 Pech, 'The Rule of Law as a Constitutional Principle of the European Union'.

$82 \quad$ Next Steps for a Sustainable European Future, p. 11.

83 Ibid., p. 12. 
security and justice and the Structural Reform Support Service. ${ }^{84}$ Externally, the EU links the achievement of Goal 16 to the broad spectrum of its policies, emphasizing inter alia the EU's response to violent conflicts. Referring to democracy, good governance and the rule of law as preconditions for sustainable development and stability, the 2017 New European Consensus on Development emphasizes the support to justice and security sector reforms and calls for a stronger nexus between development and conflict resolution. ${ }^{85}$

Consequently, the respective EU policy documents, adopted in line with the EU's commitment to the 2030 Agenda, do not comprehensively conceptualize the rule of law, especially in its external dimension. Although the substance of the rule of law in the external domain of the EU's activities is subject to a continuing open-ended debate, ${ }^{86}$ it needs to be underlined that the respective documents call for the integration of the EU's internal and external rule of law promotion policies. ${ }^{87}$ This allows emphasizing the use of the 2014 Rule of Law Framework as a roadmap for the ensuing analysis. Moreover, since the 2014 Rule of Law Framework builds on the expertise of the European Commission for Democracy through Law, the subsequent analysis will also refer to the 2016 Rule of Law Checklist, as developed by the Commission. ${ }^{88}$

\section{3 \\ The Interlinkages Between the Rule of Law and Economic Development: From Development Economics to the EU's Implementation of the SDGS}

In the modern era, the relationship between the rule of law and economic development is characterized by a paradox: on the one hand, the rule of law is viewed as "a panacea for the ills of the countries in transition" and, thus, a prerequisite for sustainable development; 89 on the other hand, despite the West's zeal to promote the rule of law, BRICS and GCC countries showcase economic growth under the absence thereof. ${ }^{90}$ To understand this paradox in light of the SDGs and to distinguish key aspects of the interplay between the rule of

\footnotetext{
84 Key European Action Supporting the 2030 Agenda, pp. 57-61.

85 New European Consensus on Development, pp. 32-37.

86 Laurent Pech, 'Rule of Law as a Guiding Principle of the European Union's External Action' CLEER Working Papers 2012/2013, pp. 3-5, http://www.asser.nl/upload/ documents/2102012_33322cleer2012-3web.pdf, accessed 1 February 2019.

87 See, for instance, New European Consensus on Development, pp. 32-33.

88 Rule of Law Checklist.

89 Thomas Carothers, 'The Rule of Law Revival', Foreign Affairs, March/April 1998, pp. 1-4.

9o See, for instance, Kenneth W. Dam, The Law-Growth Nexus (Washington, DC: Brookings Institutions, 2006), pp. 1-26.
} 
law and economic development, Section 3 addresses the rule of law-economic development nexus from the standpoint of leading post-war development economics theories. Two key approaches to the rule of law in development economics theory may be distinguished: an instrumental view of the rule of law as an instrument of economic development and an emphasis on it as an independent value. These findings are subsequently applied to the analysis of the interlinkage between the rule of law and economic development in the 2030 Agenda and in EU development policy and the elaboration of the sustainable development-oriented design of the ENP.

The Rule of Law and Economic Development in Development Economics Theories

\subsubsection{Law and Post-war Development Projects}

The key task of development economics is to understand the origins of development gaps between countries and the ways to bridge them. ${ }^{91}$ The momentum for studies of the interplay between law and development resulted from post-war attempts to promote peace in Europe and globally, and to facilitate economic reconstruction and development. ${ }^{92}$ According to Kennedy and Stiglitz, in the early post-war period the role of law was limited to 'translating leading postwar economic theories into policy'. ${ }^{93}$ It is, however, notable that the post-war European Economic Community (EEC) project used legal integration as a key way to achieve peace and economic development. In particular, the first Commission's President Walter Hallstein conceptualized the EEC as a supranational legal Community (Rechtsgemeinschaft) in three senses: as a creation of law (Rechtsschöpfung), a source of law (Rechtsquelle), the legal order (Rechtsordnung) and legal policy (Rechtspolitik). ${ }^{94}$ The role of law in EEC integration was reaffirmed by the famous comparative 'Integration through Law' research project, led by Prof. Mauro Cappelletti in the $1980{ }^{95}{ }^{95}$ In other words, the EEC-specific 'integration through law' has been a crucial means of instrumentalizing economic interdependencies, lying at the core of the project's peace objectives. ${ }^{96} \mathrm{~A}$ recent revision of the 'integration through law'

91 Gerard Ronald, Development Economics (London: Routledge, 2016), p. 25.

92 David Kennedy and Joseph Stiglitz (eds.), Law and Economics with Chinese Characteristics (Oxford: Oxford University Press, 2013), pp. 23-24.

$93 \quad$ Ibid., p. 25.

94 Walter Hallstein, Die Europäische Gemeinschaft (Düsseldorf/Vienna: Econ Verlag, 1979), p. 53 .

95 Mauro Cappeletti, Monica Seccombe and Joseph Weiler, Integration through Law: Europe and the American Federal Experience (Berlin: Walter de Gruyter, 1986), pp. 1-16.

$96 \quad$ Ibid. 
concept in the post-Lisbon EU demonstrates that, despite normative concerns, the concept remains relevant for the EU's further evolution. ${ }^{97}$

While the EEC integration project demonstrates the potential of the lawcentric approach to economic development, the first attempt to "export" Western laws and institutions to Southeast Asia and Latin America through the Law \& Development Movement in the 1960s was unsuccessful. Led by the U.S. Agency for International Development, the Law \& Development Movement was based on the modernization theory, developed by Walt Rostow and David Apter. ${ }^{98}$ According to these modernization theorists, the cause of societies' underdevelopment lies in their traditional economic, political, legal and cultural structures that require undergoing an evolutionary modernization process. ${ }^{99}$ This process was viewed as systemic, transformative and irreversible. ${ }^{100}$ Thus, the Law \& Development Movement, sought to promote progress through legal reforms, resembling the conventional "menu" of the rule of law promotion. ${ }^{101}$ Understood as a "homogenizing process", Law \& Development Movement did not aim at economic development per se, but sought to "westernize" target societies. ${ }^{102}$ Not surprisingly, the Law \& Development Movement's statecentrism and ignorance towards the specificities of socioeconomic structures in these societies resulted in the collapse of this project. ${ }^{103}$

Why did the 'integration through law' approaches succeed in Europe, while the Law \& Development Movement failed? The response seems to lie in the nature and objectives of these processes. First, while the European project focused on integration, based on a "united in diversity" principle, the Law \& Development Movement sought to homogenize societies by "transplanting"

97 Daniel Augenstein and Mark Dawson, 'What Law for What Polity? "Integration through Law" in the European Union Revisited' in Daniel Augenstein (ed.), Integration through Law Revisited. The Making of the European Polity (Farnham: Ashgate, 2012), pp. 1-4.

98 Walt Whitman Rostow, 'The Stages of Economic Growth', The Economic History Review, 12/1:1-16 (1959), pp. 1-10; David Ernest Apter, The Politics of Modernization (Chicago: Chicago University Press, 1965), pp. 67-90.

99 Rostow, 'The Stages of Economic Growth', pp. 1-3.

100 Giovanni Reyes, 'Four Main Theories of Development: Modernization, Dependency, World-System and Globalization', Nomadas - Revista Crítica de Ciencias Sociales y Jurídicas, 4:1-18 (2001), pp. 2-4.

101 Thomas Carothers, Promoting the Rule of Law Abroad: In Search of Knowledge (Washington, DC: Carnegie Endowment for International Peace, 2010), pp. 7-8.

102 Reyes, 'Four Main Theories of Development', pp. 3-4.

103 David Trubeck and Mark Galanter, 'Scholars in Self-Estrangement: Some Reflections on the Crisis in Law and Development Studies in the USA', Wisconsin Law Review, 4: 1062-1103 (1974). 
foreign legal structures. ${ }^{104}$ Furthermore, the modernization theory lacked clear mutually beneficial objectives of peace and economic development that were the "guiding stars" of the EEC. ${ }^{105}$ This demonstrates that, notwithstanding the specific role of law, it may be beneficial to prioritize economic integration and cooperation vis-à-vis homogenizing value-promotion efforts. Coupled with the knowledge on the role of law as an instrument of EEC integration, the above insights need to be kept in mind in the implementation of the 2030 Agenda.

3.1.2 The Era of Economics: Dependency and World-systems Theories The collapse of the Law \& Development Movement conditioned the rise of theories emphasizing economic factors of development. The dependency theory emerged in the 1950s as a result of the research by the European Commission for Latin America and the Caribbean. ${ }^{106}$ According to Giovanni Reyes, the dependency theory represents a combination of neo-Marxism and Keynes' economic liberalism. ${ }^{107}$ Pursuant to the key representative of this theory, Paul Prebisch, development gaps are caused by countries' differentiating roles in the global economic interdependencies' systems. ${ }^{108}$ To boost a State's role externally, Prebisch suggested strengthening the government's development, investment and industrialization policies. ${ }^{109}$ The dependency theory also emphasized strengthening the domestic market via larger internal demand that should have been achieved through wages' increase and effective coverage of social services. ${ }^{110}$

The internationalization of financial and trade systems in the 196os gave rise to the world-systems theory, whose key proponents were Fernand Braudel, Andre Frank and Immanuel Wallerstein. ${ }^{111}$ In the same vein to the dependency theory, it stressed States' role in the 'international division of

\footnotetext{
104 Ibid., pp. 1062-1065.

105 Ibid.

106 Reyes, 'Four Main Theories of Development', p. 5.

107 Ibid.

108 Paul Prebisch, 'The Economic Development of Latin America and Its Principal Problems', 1950, pp. 8-15, http://archivo.cepal.org/pdfs/cdPrebisch/oo2.pdf, accessed 1 February 2019.

109 Ibid., pp. 8-15, 43-49.

110 Ibid., p. 13.

111 Fernand Braudel, The Mediterranen and the Mediterranean World in the Age of Philipp II (Berkeley: University of California Press, 1995); Andre Frank and Barry Gills, The World System: Five Hundred Years or Five Thousand? (London: Routledge, 1993); Immanuel Wallerstein, World-Systems Analysis: An Introduction (Durham: Duke University Press, 2004).
} 
labour. ${ }^{112}$ Contrary to the dependency theory that focused on a nation-state as a unit of analysis, the world-systems theory tended to emphasize international structures which constrained economic development. ${ }^{113}$ However, similarly to the dependency theory, the world-systems theory underlined the strength of central governments, domestic markets and working class as the key driver of States' success. ${ }^{114}$

The dependency and world-systems theories undoubtedly changed the previously dominant inward-looking State-centric perception of development factors, emphasizing the economic aspects of States' participation in regional integration structures and liberalizing trade. ${ }^{115}$ Given the increasing proliferation of regional economic arrangements, such as free trade agreements, customs unions and currency blocks in global economy, the interlinkages between trade liberalization and sustainable development are highlighted in both the 2030 Agenda and the Addis Ababa Action Agenda. ${ }^{116}$

\subsubsection{Law Comes Back with Two Faces}

In the beginning of the 1990s, the rise of the new institutional economics and the challenge of supporting the economies of the post-Soviet states 'brought law and legal institutions back into the development picture.'17 The origins of the new institutional economics were rooted in two leading articles by Richard Coase. ${ }^{118}$ The key feature of the new institutional economics was its focus on social and legal institutions, underlying economic development. ${ }^{119}$ According to Douglass North, institutions are 'humanly devised constraints that structure political, economic and social interaction. ${ }^{120}$ In new institutional economics

\footnotetext{
112 Wallerstein, World-System Analysis: An Introduction, p. x.

113 Ibid., pp. 42-44.

114 Immanuel Wallerstein, Africa: The Politics of Unity (New York: Random House, 1977), pp. $30-35$.

115 Kennedy and Stiglitz, Law and Economics with Chinese Characteristics, p. 36.

116 Transforming Our World: The 2030 Agenda for Sustainable Development, pp. 8, 16, 20; UNGA, Addis Ababa Action Agenda of the Third International Conference on Financing for Development, A/RES/69/313, 27 July 2015, pp. 3-4.

117 John K. M. Ohnesorge, 'Developing Development Theory: Law and Development Orthodoxies and the Northeast Asian Experience', University of Pennsylvania Journal of International Law, 28/2: 219-308 (2014), p. 244.

118 Ronald Harry Coase, 'The Nature of the Firm', Economica 4/16: 386-405 (1937); Ronald Harry Coase, 'The Problem of Social Cost', The Journal of Law and Economics, 3: 1-44 (1960).

119 Coase, 'The Nature of the Firm', p. 391.

120 Douglass North, 'Institutions', The Journal of Economic Perspectives, 5/1: 97-112 (1991), p. 97.
} 
terms, 'constitutions, laws and property rights' represent key formal institutions, defined as 'humanly devised constraints that structure political, economic and social interaction' that allow capturing the gains from trade and avoiding negative externalities. ${ }^{121}$

The legal protection for property rights was the single explicit law-related component included into the famous Washington Consensus in the early 198 os. $^{122}$ The Washington Consensus embraced ten policy prescriptions, constituting a standard reform package, promoted by the Washington institutions, including the IMF and the World Bank. ${ }^{123}$ The key feature thereof, as compared to the dependency and world-systems approaches, has been limiting the State's role in economy in order to support private economic activities. ${ }^{124}$

Soon thereafter, the rise of the new institutional economics led the World Bank's discursive shift from the solely economic agenda to the governance paradigm which led in turn to the revival of the rule of law principle. ${ }^{125}$ The above shift resulted in the Washington Consensus being supplemented with additional dimensions, such as corporate governance, labor standards and World Trade Organization agreements. ${ }^{126}$ The change of the World Bank's policies led to development professionals' increased attention to two major aspects of States' legal systems: the systemic characteristics of constitutional law, allowing for the observance of fundamental values, and private law. The former resulted inter alia in the development of new constitutionalism, viewing re-politicization of politics via civic participation and independent judicial review as key objectives of countries' legal developments ${ }^{127}$ Thus, the emergence of governance and new constitutionalism conditioned the rise of two visions of law in development economics: the instrumental and the one that views law as an independent value and objective.

\footnotetext{
121 Ibid.

122 World Bank, Accelerated Development in Sub-Saharan Africa - An Agenda for Action, 14030/1981, http://documents.worldbank.org/curated/en/702471468768312009/pdf/multipage.pdf, accessed 1 February 2019.

123 Ibid.

124 F. Charles Sherman, 'Law and Development Today: The New Developmentalism', German Law Journal, 10/9: 1257-1273 (2011).

125 Ibid., pp. 304-307.

126 Dani Rodrik, 'Goodbye Washington Consensus, Hello Washington Confusion? A Review of the World Bank's Economic Growth in the 199os: Learning from a Decade of Reform', Journal of Economic Literature, 44/4: 973-987 (2006).

127 Ran Hirschl, 'The Judicialization of Politics' in Robert E. Goodin (ed.), The Oxford Handbook of Political Science (Oxford: Oxford University Press, 2013).
} 
The latter vision is reflected not only in the "augmented" Washington Consensus, introduced in $1989,{ }^{128}$ but also in the recent two decades of the EU's foreign policy. This thesis can be substantiated by the strengthening of the role of the rule of law in the EU's external policy over the period from the adoption of the Single European Act (SEU) to the Lisbon Treaty; the disentanglement from economic objectives; and the EU's rule of law promotion beyond its borders. ${ }^{129}$ Furthermore, as it is exemplified by a number of EU missions in conflict-affected societies (e.g. EUJUST THEMIS in Georgia, EULEX in Kosovo and EUAM in Ukraine), the EU's external rule of law promotion is tightly linked to its conflict resolution activities. ${ }^{130}$ The nexus between the rule of law and conflict resolution provides additional evidence regarding the co-existence of two approaches to the rule of law, distinguished above, in the EU foreign policy.

The foregoing discussion on the nexus between the rule of law and economic development in development economics theory allows for highlighting several takeaways. First, law and the rule thereof represent a crucial instrument for achieving economic objectives. Second, since the 199os, the rule of law has become a self-standing value and objective to be achieved within development cooperation efforts. Given the fact that legal development represents an integral part of societies' evolution, such trend has been a valuable supplement to the previously economic-centered dependency, world-systems and Washington Consensus approaches. The negative side of an emphasis on the rule of law as a self-standing value and objective of development cooperation seems to deal with the devaluation of an instrumental meaning of the rule of law. Since the SDGs emphasize interlinkages between the Goals and encompass many cross-cutting themes that require high-quality regulation at both international and domestic levels (e.g. trade, financial markets), the above threat is highly relevant for the implementation of the 2030 Agenda. Thus, the article suggests viewing the rule of law both as an independent objective of the 2030 Agenda and an instrument of promoting economic development.

128 Rodrik, 'Goodbye Washington Consensus, Hello Washington Confusion?', p. 978.

129 Pech, 'Rule of Law as a Guiding Principle of the European Union's External Action', pp. $3^{-5}, 13^{-22}$.

130 European Parliament, EU Support for Democracy and Peace in the World, Briefing 628271/2018, http://www.europarl.europa.eu/RegData/etudes/BRIE/2018/628271/EPRS_ BRI(2018)628271_EN.pdf, accessed 1 February 2019. 


\section{The Rule of Law and Economic Development in the 2030 Agenda: Interlinkages between the Goals and Policy Coherence for Sustainable Development}

According to the Partnership pillar of the 2030 Agenda, 'the interlinkages and integrated nature of the Sustainable Development Goals are of crucial importance in ensuring that the purpose of the new Agenda is realized'.131 By pointing to the sustainable nature of economic development, the document automatically promotes the growth-environmental protection nexus. ${ }^{132}$ Based on the above, the Agenda refers to democracy, good, governance and the rule of law as essential factors for sustainable development. ${ }^{133}$ This formulation and the Agenda's referral to the rule of law as a means to promote peace and security testify to the Agenda's instrumental approach to the rule of law. In other contexts, however, the Agenda mentions the rule of law and respect for international law in an independent fashion showcasing the co-existence of legal instrumentalism and "law as a value-in-itself" approaches. ${ }^{134}$

Surprisingly, despite the emphasis on the interlinkages between the Goals in its Vision section, the Agenda barely points to such interplay in its substantive part. ${ }^{135}$ Similarly, the SDGs-related targets and indicators are of a Goal-specific nature, and Goals do not share targets or indicators. ${ }^{136}$ The economic development-related targets and indicators under Goal 8, promoting 'sustained, inclusive and sustainable economic growth, full and productive employment and decent work for all' (e.g. targets 8.1, 8.2. and 8.3) do not refer to either domestic/ international law or the rule of law. ${ }^{137}$ Target 8.8 ("protect labour rights and promote safe and secure working environments') and indicator 8.8.2 ('increase in national compliance of labour rights') represent the only case that Goal 8 refers to law. ${ }^{138}$

Turning now to Goal 16 on the promotion of peaceful and inclusive societies for sustainable development, it is worth mentioning that it only addresses development in the title. The targets and indicators under Goal 16 do not identify the interlinkages between peaceful and inclusive societies and the rule of law, on the one hand, and economic development, on the other. ${ }^{139}$ Pursuant to the

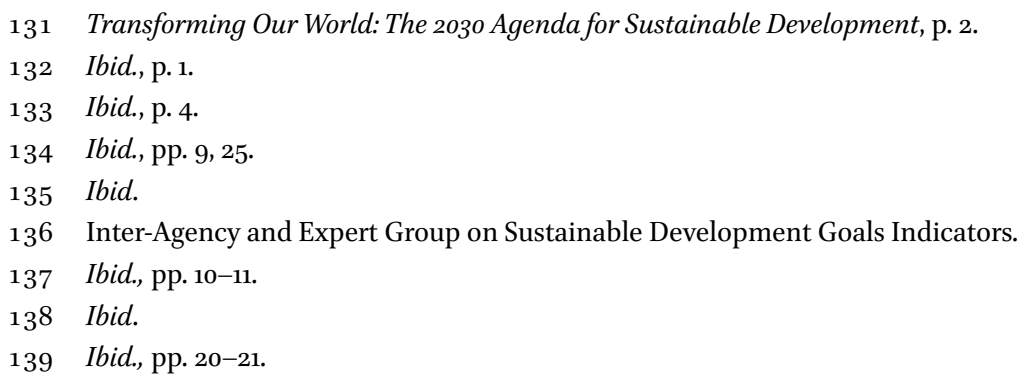


analysis of the negotiations on Goal 16 in the Open Working Groups by Noora Arajärvi, the Agenda's non-linking of the rule of law and economic development results from the politicization of the peace, governance and the rule of law agenda in the SDG s. ${ }^{140}$ Hence, due to the opposition of non-democratic powers (e.g. Russia, China) to 'supplementing the sustainable development concept with the governance dimension', Goal 16 ended up being under-ambitious and disconnected from the economic development agenda. ${ }^{141}$

As it was mentioned earlier, a notable feature of the 2030 Agenda is the expansion of the focus on the means of implementation. ${ }^{142}$ Despite the fact that the visionary part of the Agenda repeatedly refers to the importance of interlinkages between the Goals, Goal 17 on the strengthening of the means of implementation does not use this notion. Instead, Goal 17 emphasizes policy coherence in two aspects. First, it refers to macroeconomic policies' coherence (coherence between fiscal, trade, investment and regulatory aspects of public policy). ${ }^{143}$ Second, Goal 17 introduces a new expansive concept of Policy $\mathrm{Co}_{0}$ herence for Sustainable Development, without defining it. ${ }^{144}$ According to the approach of the Organisation for Economic Co-operation and Development (OECD), Policy Coherence for Sustainable Development seeks to go beyond the donor-only approach and strengthen the focus on cross-sector synergies. ${ }^{145}$ Thus, Policy Coherence for Sustainable Development aims to increase the governments' ability to reconcile their domestic policy objectives with internationally agreed ones; to facilitate synergies between economic, social and environmental dimensions of sustainable development; and address the spillovers of domestic policies. ${ }^{146}$ As underlined by the OECD, Policy Coherence for Sustainable Development shall involve coherence among international actors; coherence between the actions of different players (governments, private sector, csos); coherence between different funding sources and, finally, coherence between various policies. ${ }^{147}$ The role of Policy Coherence for Sustainable Development in

\footnotetext{
140 Noora Arajärvi, 'The Rule of Law in the Agenda 2030', The Hague Journal of the Rule of Law, 10/1: 187-217 (2018).

141 Ibid.

142 Transforming Our World: The 2030 Agenda for Sustainable Development, p. 28.

143 Ibid., p. 27.

144 Ibid.

145 Ebba Dohlman, Towards Policy Coherence for Inclusive and Sustainable Development, Presentation, Office of the Secretary-General OECD, 12 June 2014, p. 7, https://ec.europa .eu/europeaid/sites/devco/files/presentation-oecd-experience-thinking-pcd-20140612_ en.pdf, accessed 1 February 2019.

146 Ibid., pp. 7-8.

147 Ibid.
} 
the SDGs' implementation is, however, questionable. ${ }^{148}$ The Means of Implementation section of the Agenda does not add clarity with respect to either the Policy Coherence for Sustainable Development or the integrated approach to Goals. Referring to domestic resources' mobilization, private business and international trade as cross-cutting prerequisites for sustainable development, it does not relate them to the Policy Coherence for Sustainable Development or the inter-linkages between the Goals. ${ }^{149}$ Importantly, the Policy Coherence for Sustainable Development, as presented in the 2030 Agenda, is disconnected from the idea of interlinkages between the Goals, in general, and the interlinkages between the rule of law and economic development, in particular. ${ }^{150}$ This approach is highly dissimilar to the one of the Addis Ababa Action Agenda that emphasizes specific domains of international and national law to be improved in terms of the actions and policies it suggests. For instance, the Addis Ababa Action Agenda refers to international trade law as a means to promote trade that, in turn, serves as an engine for development. ${ }^{151}$

The analysis reveals that, despite the Agenda's emphasis on the interlinkages between the Goals, the formulations of Goals 8 and 16, and respective targets and indicators barely conceptualize the interlinkage between economic development and the rule of law in the context of sustainable development. Furthermore, the ambitious Policy Coherence for Sustainable Development, introduced by Goal 17, is disconnected from both the notion of interlinkages between the Goals, in general, and the interlinkages between the rule of law and economic development, in particular. This is sharply different from the Agenda's ambition to revitalize the global partnership that manifests itself in concrete policies and actions, specified inter alia in the Addis Ababa Action Agenda. ${ }^{152}$

The Relationship between the EU's Policy Coherence for Development and Value-Promotion before the Adoption of the 2030 Agenda

In the EU, the principle of policy coherence for development has been the subject of debate since the introduction of the EU's obligation 'to act as a cohesive force in international relations', stipulated by the Article $30(\mathrm{~d})$ of the Single

\footnotetext{
148 James Mackie, Martin Ronceray, Eunike Speurings, 'Policy Coherence and the 2030 Agenda: Building on the PCD Experience', ECDPM Discussion Paper, 10/2017, pp. 3-8.

149 Transforming Our World: The 2030 Agenda for Sustainable Development, pp. 28-31.

$150 \quad$ Ibid., p. 27.

$15^{1}$ Addis Ababa Action Agenda, pp. 23-25.

$15^{2}$ Ibid, p. 5 .
} 
European Act. ${ }^{153}$ According to Carbone, in the pre-Maastricht era, coherence predominantly referred to the relationship between the EU and Member States in the CFSP domain. ${ }^{154}$ The emphasis on horizontal coherence between the EU's external policies was first reflected in the TEU(M). ${ }^{155}$ As opposed to vertical coherence, which stresses the processes of coordination and bargaining between the Member States and the EU, horizontal coherence focuses predominantly on the implementation of the EU policies. ${ }^{156}$

Despite the EU's duty to consider development-related objectives in the implementation of its respective policies, stipulated in Article 130(v) TEU (M), policy coherence within the development cooperation domain was rarely debated before the adoption of the MDGs. ${ }^{157}$ Following five years of increasing aid volumes, attempts to improve its delivery, and uneven progress, the Commission adopted its Communication on Policy Coherence for Development. ${ }^{158}$ Going beyond the TEU(M), this Communication not only associated policy coherence for development with the non-contradiction between aid and nonaid policies but also supported the utilization of non-aid policies to enhance development objectives. 159 This Communication did not provide for connections between Policy Coherence for Development and EU values. The EU's commitment to Policy Coherence for Development was reaffirmed in the 2006 European Consensus on Development, emphasizing trade and security aspects of the Policy Coherence for Development. ${ }^{160}$ Importantly, the 2006 European Consensus on Development was the first EU policy document to link the EU's development policies to its external value-promotion by stipulating

153 European Communities, 'Single European Act', Official Journal of the European Communities, L 169/1, 29 June 1987, 13.

154 Maurizio Carbone, 'Mission Impossible: the European Union and Policy Coherence for Development', Journal of European Integration, 30/3:323-342 (2008), p. 323.

155 TEU (M), Article 130(v).

156 Clara Portela and Kolja Raube, 'The EU Policy and Foreign Policy Coherence,' Journal of Contemporary European Research, 8/1: 3-20 (2012), p. 5.

157 Carbone, 'Mission Impossible', p. 325.

$15^{8}$ European Commission, Communication to the Council, the European Parliament and the European Economic and Social Committee, Policy Coherence for Development Accelerating Progress towards Attaining the Millennium Development Goals, сом(2005) 134 final, 12 April 2005.

159 Ibid., p. 2.

160 Council of the European Union, the representatives of the governments of the Member States meeting within the Council, the European Parliament and the Commission on EU Development Policy, The European Consensus, 2006/C46/o1, https://ec.europa.eu/europeaid/sites/devco/files/publication-the-european-consensus-on-development-2006o6_ en.pdf, accessed 1 February 2019. 
common values, political dialogue and support for civil society participation. ${ }^{161}$ Following the critical Commission's 2007 Report on Policy Coherence for Development and the, more optimistic, 2009 respective Report, the Commission called for establishing the framework for a "whole-of-the-Union" approach to Policy Coherence for Development. ${ }^{162}$ The 2009 Commission's Communication on the Policy Coherence for Development aimed at establishing 'a more strategic, systematic and partnership oriented approach to [Policy Coherence for Development].'163 However, besides the emphasis on the interplay between the Official Development Assistance and non-Official Development Assistance aid flows and the EU internal policies' impact on the Policy Coherence for Development, the Communication did not significantly change the scope of the Policy Coherence for Development concept. ${ }^{164}$ Similarly to the 2005 Policy Coherence for Development Communication, the "whole-of-the-Union" approach did not link Policy Coherence for Development to the promotion of EU values. ${ }^{165}$

Thus, upon the Commission's 2016 Communication on the Next Steps for a Sustainable European Future, and after an almost ten-year Policy Coherence for Development experience, the EU undertook the commitment to implement highly inter-linked SDGs. An important feature of the EU's overall Policy Coherence for Development has been the conceptual separation from the EU's external value-promotion agenda, as demonstrated across all the presently discussed documents (with the exception of the 2006 European Consensus on Development). The question that now needs to be addressed is whether the EU's commitment to the SDGs and the adoption of the TEU(L) address and somehow bridge this conceptual separation. The answer to this question is to be found in the 2017 New European Consensus on Development that is discussed in the following sub-section.

\footnotetext{
$161 \quad$ Ibid.

162 Ulrike Zeigermann, 'Governing Sustainable Development through "Policy Coherence”? The Production and Circulation of Knowledge in the EU and the OECD', European Journal of Sustainable Development, 7/1: 133-149 (2018), p. 142.

163 Commission of the European Communities, Communication to the Council, the European Parliament, the European Economic and Social Committee and the Committee of the Regions, Policy Coherence for Development - Establishing the Policy Framework for a Whole-of-the-Union Approach, $\operatorname{coм}(2009) 458$ final, 15 September 2009, p. 7.

164 Ibid.; Council of the EU, Council Conclusions on Policy Coherence for Development (PCD), $2974^{\text {th }}$ External Relations Council Meeting, 17 November 2009, http://www.consilium.europa.eu/uedocs/cms_Data/docs/pressdata/en/gena/111278.pdf, accessed 1 February 2019.

165 Policy Coherence for Development - Establishing the Policy Framework for a Whole-of-theUnion Approach.
} 


\subsection{Strengthening the Role of the Rule of Law in the EU but Not Due to the SDGs}

The 2017 New European Consensus on Development is the cornerstone for the EU's action, directed to achieving the SDGs. ${ }^{166}$ The 2017 New European Consensus on Development refers to development policy as part of the EU's external action, and emphasizes the need to support democracy, human rights and the rule of law as the objectives thereof. ${ }^{167}$ An emphasis on the overarching nature of the above objectives distinguishes the post-Lisbon 2017 New European Consensus on Development from earlier coherence-oriented documents. According to Vivian Kube, the operationalization of values in the form of objectives of the EU's external action shall have far-reaching consequences for balancing gener$\mathrm{al}$ and policy-specific objectives within various domains of external action. ${ }^{168}$

In line with Article 21(1) TEU, the 2017 New European Consensus on Development recognizes values as guiding principles of the EU's development policy that are to be promoted within the EU's political dialogue with third countries and support for civil society. ${ }^{169}$ This illustrates the consolidation of the 2017 New European Consensus on Development approach to the rule of law as a "value-in-itself" that is, as it will be demonstrated below, complemented with a more instrumental vision. Thus, along with human rights, youth and migration, the rule of law is mentioned as a cross-cutting element that it is necessary to achieve sustainable development. ${ }^{170}$ The Peace axis of the 2017 New European Consensus on Development reaffirms the EU's and Member States' commitment to value-promotion, emphasizing its importance for sustainable development. ${ }^{171}$ Furthermore, the 2017 New European Consensus on Development mentions a range of interlinkages, such as the linkage between the rule of law and environmental degradation, the poverty eradication-conflict prevention nexus and the rule of law as means to promote stability and security. ${ }^{172}$ Without referring to either the coherence of macroeconomic policies or the Policy Coherence for Sustainable Development, the 2017 New European Consensus on Development underlines the Policy Coherence for Development's role as

\footnotetext{
166 New European Consensus on Development, pp. 3-4.

167 Ibid., p. 6.

168 Vivian Kube, 'The European Union's External Human Rights Commitment: What is the Legal Value of Article 21 TEU?', EUI Law Working Paper 10/2016, http://cadmus.eui.eu/bitstream/handle/1814/40426/LAW_2016_10.pdf?sequence=1\&isAllowed=y, accessed 1 February 2019.

169 TEU (L), Article 21; New European Consensus on Development, p. 7.

$170 \quad$ New European Consensus on Development, p. 9.

171 Ibid., pp. 32-37.

172 Ibid.
} 
a 'crucial element of the strategy to achieve the SDGs' and calls for stronger synergies in trade, investment and climate change domains. ${ }^{173}$ Building on coordination and complementarity principles, the document provides for a "whole-of-the-government" approach and for coordination and political oversight at all levels of SDGs' implementation. ${ }^{174}$

The EU's commitment to SDGs' implementation led to the restructuring of the EU's approach to development policy. Nonetheless, in spite of the Agenda's 2030 emphasis on the interlinkages between the Goals, the 2017 New European Consensus on Development barely strengthened the rule of law-economic development nexus. Instead, the 2017 New European Consensus on Development definitely reflected the renewed attention to the rule of law in the development context, stemming from the introduction of the general objectives of the EU's external action by the Lisbon Treaty. It is noteworthy that, as opposed to the emphases on the diversification of funding sources and tailor-made partnerships in the 2030 Agenda, the Consensus' push for strengthened Policy $\mathrm{Co}_{\mathrm{o}}$ herence for Development was barely translated into intra-EU policies. With the 2030 Agenda's and the OECD's ambition to promote both the ambitious and vague Policy Coherence for Sustainable Development concept, the future of both Policy Coherence for Development and Policy Coherence for Sustainable Development concepts and their reflection in further EU policies (besides the $2017 \mathrm{New}$ European Consensus on Development) is questionable.

\section{Towards a Coherent Sustainable Development-oriented Design of the Eastern Dimension of the ENP}

\subsection{The ENP: A Unique Cross-cutting Policy Field in Need of Change}

In their literature review, dedicated to the ENP, Exadaktylos and Lynggaard distinguish a range of 'intertwined characteristics' that mark this policy field and make studying it a 'challenging endeavor.' ${ }^{175}$ First, the European Neighbourhood is a 'constructed geographical space' that engages highly diverse regions with various political, economic and societal institutions. ${ }^{176}$ Second, and crucial for this article, is that the revised $2015 \mathrm{ENP}$ 'addresses literally any

\footnotetext{
173 Ibid., p. 52.

174 Ibid., p. 53 .

175 Theofanis Exadaktylos and Kennet Lynggaard, 'Research Design in the Study of the European Neighbourhood Policy' in Bouris and Schumacher, The Revised European Neighbourhood Policy, p. 37 .

176 Ibid., p. 38 .
} 
policy and cooperation sector' and 'reflects the EU's more general ambition to play a role as a conflict resolution and transformation entrepreneur in its "near abroad"'.177

The ENP as an area of research cuts across traditional research agendas, including foreign policy and Europeanization. ${ }^{178}$ What is also missing from the ENP research, is the conceptualization of the EU's role as a development actor in its "near abroad" and, hence, the coherence between the EU's reformed development policy and the ENP. ${ }^{179}$ The need for respective research and reconsideration of the overall design of the ENP, as well as its Eastern dimension, in particular, is conditioned to a number of considerations.

First and foremost, according to the Communication Next Steps for a Sustainable European Future, the ENP represents one of the crucial instruments of the EU's SDGs' implementation. ${ }^{180}$ This observation evidently is in line with the substance of transformation that the EU promotes in the Eastern Neighbourhood (e.g. political development, macroeconomic growth and stabilization, SMEs' development, green economy). ${ }^{181}$ Second, despite the fact that the 2017 Commission's and High Representative of the EU for Foreign Affairs and Security Policy's joint report on the implementation of the ENP stipulates that the 2015 ENP Review's is in conformity with the 2030 Agenda, the substance and language of the ENP documents are highly different from the Agenda. ${ }^{182}$ Three relevant examples demonstrate this point.

First, the foundational documents of the ENP barely address the coherence between the EU and Member States policies vis-à-vis the associated Neighbourhood and give even less attention to the coherence between EU policies. ${ }^{183}$ Second, while both the Commission's 2008 Communication on

\footnotetext{
177 Ibid., p. 37 .

178 Ibid., p. 38 .

179 Kostanyan Hrant, 'Introduction' in Kostanyan Hrant (ed.), Assessing European Neighbourhood Policy - Perspectives from the Literature (London: Rowman and Littlefield, 2017), p. 4.

180 Next Steps for a Sustainable European Future, p. 12; Key European Action Supporting the 2030 Agenda, p. 8.

181 Exadaktylos and Lynggaard, 'Research Design in the Study of the European Neighbourhood Policy', p. 37.

182 European Commission and the High Representative of the Union for Foreign Affairs and Security Policy, Report on the Implementation of the European Neighbourhood Policy Review, Join (2017) 18 final, 18 May 2017, p. 4.

183 Commission of the European Communities, Eastern Partnership, сом(2008) 823 final, 3 December 2008; European Commission and the High Representative of the Union for Foreign Affairs and Security Policy, Review of the European Neighbourhood Policy, JOIN (2015) 50 final, 18 November 2015 .
} 
Eastern Partnership and the 2015 ENP Review emphasize facilitation of bi- and multilateral cooperation between target countries and the EU's cooperation with regional organizations, they rarely refer to the EU's development-oriented partnership with other stakeholders and related coherence issues. ${ }^{184}$ Evidently, such approach contradicts the Agenda's 2030 ambition to introduce a multi-aspect Policy Coherence for Sustainable Development concept. Third, the 2008 Communication on Eastern Partnership distinguishes five independent focus points of the EU's bilateral cooperation with the Eastern Partnership states (that include inter alia support to partner countries' economic development and striving for progress in the rule of law domain) without mentioning cross-cutting issues or interlinkages between the objectives. ${ }^{185}$ Despite conceptualizing stabilization of the Neighbourhood as a complex process and pointing to cross-cutting challenges (mostly in the security and migrationrelated domains), the 2015 ENP Review fails to adopt an instrumental approach to the rule of law and legal reform. ${ }^{186}$ As opposed to the 2017 New European Consensus on Development, the 2015 ENP Review considers the rule of law only in conjunction with democracy and human rights promotion, and does not link it either to economic development/modernization or the security/ stability problematique. ${ }^{187}$

Though brief, the analysis suggests that the ENP framework documents were not adapted to the novelties of the 2030 Agenda and the reformed EU development policy, such as elaborate Policy Coherence for Sustainable Development requirements, the EU's leading role in the international developmentoriented partnerships and the focus on the interlinkages between the action fields. In particular, pursuing umbrella policy objectives, such as the promotion of fundamental values and Neighbours' economic development, the EU would supposedly benefit from introducing a pragmatic approach to the rule of law alongside its appraisal as a value and a stronger account of synergies and interlinkages between the rule of law and economic development in the Association Agreements with Ukraine, Moldova and Georgia. Some of the respective synergies will be highlighted below, based on the example of traderelated parts of these Agreements.

\footnotetext{
184 Ibid.

185 Eastern Partnership.

186 Review of the European Neighbourhood Policy.

187 Ibid.
} 


\subsection{The Deep and Comprehensive Free Trade Areas (DCFTAS) with the Eastern Neighbors and the Hidden Synergies}

The unique position of EU Association Agreements (AAs) with Eastern Neighbours in the overall system of EU AAs with third countries is determined by their comprehensive nature, their elaborate conditionality structures, the ambitious scope of Neighbours' legislation's approximation to acquis communautaire, and their dispute settlement mechanisms. ${ }^{188}$ The comprehensiveness of the AAs' scope is manifested inter alia in the Agreements' trade-related chapters that go far beyond liberalizing trade in goods: they encompass, for example, norms on non-tariff barriers to trade countering non-financial markets, competition and state aid, and electronic commerce. ${ }^{189}$ According to Billy Araujo, the EU's modern "deep" trade agenda does not only serve as a vector of the evolution of the EU's identity in foreign affairs but also represents a powerful means to impact third countries' legal systems. ${ }^{190}$ The "black letter law" analysis of the AAs (with a focus on their trade-related parts) allows for distinguishing several categories of these Agreements' norms that promote the rule of law.

To start, it is noteworthy that the AAs with Eastern Neighbors include common values conditionality by embracing essential element clauses (specifying core values on which 'the relationships between the parties are premised') and suspension clauses (defining procedures for suspending the agreement in case of violation of the essential elements). ${ }^{191}$ Common values' conditionality is marked by the breadth of essential elements that encompass inter alia the security dimension and adherence to market economy principles. ${ }^{192}$

188 Roman Petrov, 'Association Agreements between the EU and Ukraine, Moldova and Georgia: Legal and Constitutional Challenges of Implementation', Visnyk of the Lviv University Series 'International Relations', Issue 36 (2014), pp. 15-16.

189 Association Agreement between the European Union and its Member States, on the one hand, and Ukraine OJ L161, 2014 (EU-Ukraine AA), Title IV, on the other; Association Agreement between the European Union and its Member States, on the one hand, and the Republic of Moldova, OJ L26o, 2014 (EU-Moldova AA), Title V, on the other; Association Agreement between the European Union and its Member States, on the one hand, and Georgia, OJ L261, 2014 (EU-Georgia AA), Title IV, on the other.

190 Billy A. Melo Araujo, The EU Deep Trade Agenda. Law and Policy (Oxford: Oxford University Press, 2016), pp. 40-42.

191 Gillaume Van der Loo, Peter Van Elsuwege and Roman Petrov, 'The EU-Ukraine Association Agreement: Assessment of an Innovative Legal Instrument', EUI Working Papers, 2014/o9, p. 12, http://cadmus.eui.eu/bitstream/handle/1814/32031/LAW\%20 _WP_2014_9\%20.pdf?sequence=1\&isAllowed=y, accessed 1 February 2019. 
Furthermore, the Agreements distinguish between 'hard core common values related to fundamental rights and security' and principles that underpin the relationships between the parties. ${ }^{193}$ Despite the elaborateness of the respective clauses, it is worth emphasizing that the EU applies the essential elements clauses in a highly politicized and selective fashion. ${ }^{194}$ According to Hachez' study of the EU's reaction to essential elements violations in numerous countries between 1996 to 2011, the EU does not apply essential elements conditionality often enough and, when applying it, it does so selectively, primarily to "punish" less powerful partners. ${ }^{195}$ This raises doubts with regard to the effectiveness of the essential element clause' as a rule of law promotion instrument.

Moreover, the DCFTAs with Eastern Neighbors contain separate chapters on transparency which are aimed at ensuring a predictable regulatory environment for economic operators. ${ }^{196}$ Since the principle of predictability of the regulatory environment falls within the scope of the legal certainty component of the rule of law, ${ }^{197}$ it is not surprising that the dimensions of the rule of law as distinguished in this article, pierce the substance of the DCFTA's transparency chapters. Thus, along with the predictability principle, such chapters also give expression to legal certainly standards like transparency, stability and foreseeability of laws. ${ }^{198}$ Further substantive requirements embedded into these chapters include inter alia standards related to transparency stricto sen$s u$ (e.g. publication requirements, transparency of judicial review); ${ }^{199}$ stability of legal systems and foreseeability of regulations (e.g. with respect to the administration of the measures of general application); ${ }^{200}$ citizens' equality before the law; non-discrimination; and participation. ${ }^{201}$ Furthermore, the DCFTAs' transparency chapters encompass the Eastern Neighbours' broadly

\footnotetext{
193 Ibid.

194 Nicolas Hachez, 'Essential Elements' Clauses in EU Trade Agreements Making Trade Work in a Way that Helps Human Rights?', Leuven Centre for Global Governance Studies Working Paper, 158/2015, pp. 17-18.

195 Ibid.

196 EU-Ukraine AA, Title Iv, Chapter 12; EU-Moldova AA, Title IV, Chapter 12; EU-Georgia AA, Title IV, Chapter 12.

197 Rule of Law Checklist, pp. 15-16.

198 See, for instance, EU-Moldova AA, Article 356.

199 EU-Ukraine AA, Articles 283-284, 286; EU-Moldova AA, Articles 357-358, 360; EUGeorgia AA, Articles 221-222, 224.

200 EU-Ukraine AA, Article 285; EU-Moldova AA, Article 359; EU-Georgia AA, Article 223.

201 EU-Ukraine AA, Articles 285-286, 288; EU-Moldova AA, Articles 359-36o, 362; EUGeorgia AA, Articles 223-224.
} 
formulated judicial independence and impartiality obligations. ${ }^{202}$ Compared to the classical trade liberalization-related transparency clauses, as exemplified by Article X GATT, ${ }^{203}$ transparency chapters of the EU's DCFTAs with Ukraine, Moldova and Georgia contain a more expansive and further-reaching rule of law component.

A crucial role in the promotion of the rule of law and related best practices belongs to DCFTAs' administrative and technical cooperation clauses. ${ }^{204}$ In this respect, a special value of administrative cooperation clauses lies in the fact that they bring the Eastern Neighbors' institutions under the auspices of European administrative space, founded on the principles of the rule of law and good governance. ${ }^{205}$ More specifically, according to the DCFTAs, EUNeighborhood cooperation in the domain of customs and trade facilitation pursues the objective of legitimate trade, as concerned with 'effective enforcement of, and compliance with, legislative requirements. ${ }^{206}$ An analysis of the Neighbors' obligations on administrative cooperation and leveling of technical barriers to trade also demonstrates their linkage to rule of law components (e.g. legality, transparency and accountability, adherence to the international standards). ${ }^{207}$

Last, but not least, a vital source of synergies between the rule of law and economic development is represented by "deep disciplines" such as competition and public procurement clauses in the DCFTAs. In transition studies, the establishment of functional competition and public procurement regimes is an important step in a State's transit from a centralized planned economy to free market. ${ }^{208}$ Furthermore, apart from introducing the Neighbors' substantive

202 EU-Ukraine AA, Article 286(1); EU-Moldova AA, Article 360(1); EU-Georgia AA, Article 224(1).

203 World Trade Organization, 'The General Agreement on Tariffs and Trade', July 1986, Article X, https://www.wto.org/english/docs_e/legal_e/gatt47.pdf , accessed 1 February 2019.

204 EU-Ukraine AA, Articles 80-84; EU-Moldova AA, Articles 197-201; EU-Georgia AA, Articles $71-75$.

205 Jarle Trondal and B. Guy Peters, 'The Rise of European Administrative Space: Lessons Learnt', Journal of European Public Policy, 20/2: 295-307 (2013), pp. 295-296.

206 EU-Ukraine AA, Article 75; EU-Moldova AA, Article 192; EU-Georgia AA, Article 66.

207 EU-Moldova AA, Article 193(1)(a)(b) (legality; transparency and non-discrimination dimensions of the rule of law); Articles 171, 172(2)(d)(f) (adherence to the international standards).

208 Robert H. Lande, 'Creating Competition Policy for Transition Economies: Introduction', Brooklyn Journal of International Law, 23/2: 339-349 (2017), p. 340. 
obligations with respect to selective rule of law standards, ${ }^{209}$ the chapters in question contain a uniquely diversified toolbox for promoting the rule of law, including the affirmation of Neighbors' obligations under international law, ${ }^{210}$ approximation of laws and enforcement practices, ${ }^{211}$ and obligations as regards transparency in consultations and enforcement cooperation. ${ }^{212}$ The functionality of the above tools is supported by the AAs' institutional framework, the dynamic nature of AAs, and the elaborate provisions on monitoring, financial discipline and dispute resolution.

\subsection{Towards a Sustainable Development-oriented Design of the Eastern Dimension of the ENP}

Undoubtedly, the Eastern dimension of the ENP exemplifies a policy that, despite being linked to development cooperation, has not yet been brought under the auspices of the EU's implementation of the 2030 Agenda. By way of emphasizing the integrated nature of the Goals, this sub-section suggests four broad policy recommendations that could help the EU bridge this gap.

First, it is suggested to conduct the analysis of the Eastern dimension of the ENP against the backdrop of the five axes of the 2030 Agenda (People, Planet, Prosperity, Peace and Partnership). In addition to the existing policy structure, such an exercise could help policy-makers to distinguish areas which lack sufficient attention within the policy as a whole and to create the foundation for investigating coherence between the EU's development and Neighbourhood policies. At the same time, such an analytical tool would allow policy-makers to establish the introduction of the sustainable development-oriented design conditions for the next ENP policy review.

Second, based on the insights into the evolution of the linkage between economic development and the rule of law in development economics theories, the article suggests reconsidering the approach to the rule of law in the ENP context. While the Eastern dimension of the ENP addresses the rule of law as a foundational value of the relationship between the parties, the EU would benefit from contextualizing it and emphasizing its economic significance. In particular, it is advisable to distinguish the cross-cutting areas in which the rule of law and economic development objectives are conducive to create synergies.

209 See, for instance, EU-Ukraine AA, Articles 254, 258, 262 (legality); Articles 255(2) (institutional development and public accountability), Articles 255(3), 263 (transparency); Article 265 (international standards).

210 See, for instance, EU-Ukraine AA, Article 265.

211 See, for instance, ibid., Article 263.

212 See, for instance, ibid., Article 259. 
This is especially needed in the era of complex regulatory convergence processes under the "deep disciplines" chapters (e.g. competition, state aid, public procurement and, prospectively, Neighbors joining the Digital EU). ${ }^{213}$ The focus on cross-cutting areas would mean a complex strategic planning process, and the development and application of dual benchmarking and progress measurement instruments.

Third, the re-conceptualization of the linkage between economic development and the rule of law within the ENP highlights the need for positioning synergized strategies with respect to other umbrella policy concepts, such as resilience and stabilization. In other words, it is required to develop an understanding of how action in the above-mentioned cross-cutting areas would be coherent with particular aspects of these umbrella concepts and what synergies can be developed in this respect. This is highly topical in view of the fact that the 2030 Agenda places the rule of law under the auspices of the stability and security-oriented Peace axis.

Fourth, a crucial uncertainty in both the EU's development policy and the ENP is the future of Policy Coherence for Development. Despite the Agenda's ambition to introduce these expansive concepts, the 2017 New European Consensus on Development briefly mentions Policy Coherence for Sustainable Development without either explaining the difference between the Policy Coherence for Development and Policy Coherence for Sustainable Development or introducing new Policy Coherence for Sustainable Development-oriented policies. The ENP has traditionally been absent from the EU's Policy Coherence for Development agenda and this has led to the artificial disintegration between the EU's Neighbourhood and development policies. Given the obvious linkage between the EU's development and Neighbourhood policies, and the economic development and rule of law promotion agendas, it is imperative to consider the mechanisms for bringing the ENP and the EU's value-promotion into the realm of either Policy Coherence for Development or a more ambitious Policy Coherence for Sustainable Development idea.

\section{5}

\section{Conclusion}

This article's aim was to explore the interlinkage between the concepts of the rule of law (Goal 16) and economic development (Goal 8) in the 2030 Agenda and the EU's key development policy, and, on the basis of this, to propose a

213 European Commission, 'Digital Single Market - EU Neighbours', https://ec.europa.eu/ digital-single-market/en/eu-neighbours, accessed 1 February 2019. 
new sustainable development-oriented design for the Eastern dimension of the ENP.

The insights concerning the history of the nexus between the rule of law and economic development in development economic allowed for distinguishing two approaches to the rule of law, notably as an instrument of achieving policy objectives and as a self-standing value. The analysis showed that the former approach has been known to work, if law is used as an instrument within broad integration or cooperation initiatives, rather than as top-down homogenizing initiatives. Following the vaguely formulated interlinkages between the rule of law and economic development in the 2030 Agenda, the 2017 New European Consensus on Development never actually highlighted the substance of the interlinkages between the Goals or the opportunities for applying the rule of law obligations as an instrument of economic development. Moreover, the 2017 New European Consensus on Development seems to have generated uncertainty as regards the application of coherence-related concepts contained in the 2030 Agenda, most notably the Policy Coherence for Sustainable Development.

Despite the fact that the ENP is repeatedly addressed as a pivotal instrument of the EU's development policy, the EU's policy has not yet been reformed in line with the 2030 Agenda. In view of the insights regarding the substance of the rule of law - economic development nexus in the EU's implementation of the 2030 Agenda and the background analysis of the ENP, the article suggested four policy recommendations as a foundation for the sustainable development-oriented design of the ENP. These policy recommendations include 1) analyzing the Eastern dimension of the ENP from the viewpoint of 2030 Agenda; 2) supplementing the existing understanding of the rule of law as a political value with an instrumental dimension and distinguishing cross-cutting areas for synergizing the rule of law and economic development objectives; 3) reconsidering the ENP's key umbrella concepts in view of the strengthened rule of law - economic development synergies; and 4) bringing the ENP and the broader notion of the EU's value-promotion policies under the umbrella of the reformed Policy Coherence for Development or a broader Policy Coherence for Sustainable Development concept. Implementing these recommendations would arguably constitute the foundation for the reconsideration of the interplay between the EU's development and Neighbourhood policies and for creating the integrated approach to the rule of law and economic development under the auspices of the Eastern dimension of the ENP. 